\title{
Altered CSF levels of monoamines in hereditary spastic paraparesis 10
}

\section{A case series}

Mattias Andréasson, MD, Kristina Lagerstedt-Robinson, PhD, Kristin Samuelsson, MD, PhD, Göran Solders, MD, PhD, Kaj Blennow, MD, PhD, Martin Paucar, MD, PhD,* and Per Svenningsson, MD, PhD*

Neurol Genet 2019;5:e344. doi:10.1212/NXG.0000000000000344

\section{Abstract}

\section{Objective}

To perform a comprehensive clinical characterization and biochemical CSF profile analyses in 2 Swedish families with hereditary spastic paraparesis (HSP) 10 (SPG10) caused by 2 different mutations in the neuronal kinesin heavy chain gene (KIF5A).

\section{Methods}

Structured clinical assessment, genetic studies, and neuroradiologic and electrophysiological evaluations were performed in 4 patients from 2 families with SPG10. Additional CSF analysis was conducted in 3 patients with regard to levels of neurodegenerative markers and monoamine metabolism.

\section{Results}

All patients exhibited a complex form of HSP with a mild to moderate concurrent axonal polyneuropathy. The heterozygous missense mutations c.767A $>\mathrm{G}$ and c.967C $>\mathrm{T}$ in KIF5A were found. Wide intrafamilial phenotype variability was evident in both families. CSF analysis demonstrated a mild elevation of neurofilament light (NFL) chain in the patient with longest disease duration. Unexpectedly, all patients exhibited increased levels of the dopamine metabolite, homovanillic acid, whereas decreased levels of the noradrenergic metabolite, 3-methoxy-4-hydroxyphenylglycol, were found in 2 of 3 patients.

\section{Conclusions}

We report on CSF abnormalities in SPG10, demonstrating that NFL elevation is not a mandatory finding but may appear after long-standing disease. Impaired transportation of synaptic proteins may be a possible explanation for the increased dopaminergic turnover and noradrenergic deficiency identified. The reasons for these selective abnormalities, unrelated to obvious clinical features, remain to be explained. Our findings need further confirmation in larger cohorts of patients harboring KIF5A mutations.

\author{
Correspondence \\ Dr. Andréasson \\ mattias.andreasson@ki.se
}




\section{Glossary}

5-HIAA = 5-hydroxyindoleacetic acid; ALS = amyotrophic lateral sclerosis; HSP = hereditary spastic paraparesis; HVA = homovanillic acid; KIF5A = neuronal kinesin heavy chain gene; MHPG = 3-methoxy-4-hydroxyphenylglycol; NFL = neurofilament light; PNP = polyneuropathy; SPRS = Spastic Paraplegia Rating Scale.

Hereditary spastic paraparesis (HSP) comprises a large and growing group of chronic progressive neurodegenerative diseases with varying patterns of inheritance, age at onset, and disease severity. These diseases share a common affection of the corticospinal tracts. Heterozygous mutations in the $\mathrm{N}$-terminal motor domain of the neuronal kinesin heavy chain gene (KIF5A) are associated with autosomal dominant HSP 10 (SPG10) and less commonly with CharcotMarie-Tooth type 2, with or without pyramidal signs. ${ }^{1,2}$ Rarely, mutations in this gene are also associated with cerebellar ataxia or cognitive impairment. ${ }^{2}$ In addition, a recent genome-wide association study has identified variants in the C-terminal of KIF5A associated with amyotrophic lateral sclerosis (ALS). ${ }^{3}$

KIF5A encodes one of 2 heavy chain subunits that together with 2 light chain subunits make up a tetrameric kinesin-1 protein. ${ }^{1,4,5}$ This kinesin is crucial for anterograde molecular axonal transport by binding to microtubule. ${ }^{4,6}$ At least 23 mutations in KIF5A with HSP phenotype have been reported. ${ }^{1,2,5,7,8}$

In vitro assays have demonstrated that mutant forms of the kinesin-1 protein impair the transport of cargo along microtubule. ${ }^{6}$ Furthermore, 2 studies on cultured neurons from Kif5A knockout mice and mice with mutant Kif5A have demonstrated disturbed axonal bidirectional transport of mitochondria and neurofilaments, respectively. ${ }^{9,10}$ Thus, in patients, KIF5A mutations are believed responsible for an axonopathy damaging both the central and peripheral nervous systems. ${ }^{1,5,7}$ Here, we hypothesized that patients with SPG10 would demonstrate an elevation of neurofilament light (NFL) chain in CSF.

\section{Methods}

\section{Standard protocol approvals, registrations, and patient consents}

All patients have given oral and written consent to this characterization approved by the regional ethical board in Stockholm, Sweden (2016/2503-31/2).

\section{Clinical assessments}

Patients with a known diagnosis of SPG10, followed at Karolinska University Hospital, were eligible for the study. In total, 4 patients from 2 Swedish families (A and B) with heterozygous KIF5A mutations were included (figure). Patients were assessed with standardized clinical examination that included the Spastic Paraplegia Rating Scale (SPRS),
Friedreich Ataxia Rating Scale part 1: functional staging for ataxia, Inventory of Non-Ataxia Signs, Instituto de Pesquisa Clinica Evandro Chagas Scale, Scale for the Assessment and Rating of Ataxia, and Montreal Cognitive Assessment. The inclusion of rating scales assessing cerebellar function was chosen based on reports of ataxia as a feature in patients with KIF5A mutations and other familial kinesin motor proteinopathies. $^{2,11}$ Standardized examination took place between January and March of 2018.

\section{Genetic analyses}

Both families were examined with targeted genetic analyses for autosomal dominant HSP (e-Methods, links.lww.com/ NXG/A160).

\section{Biochemical analyses}

CSF was collected from 3 patients (III: 1 in family A and II: 1, III: 1 in family B) by standard procedures. Patient II: 1 , in family A, declined lumbar puncture. For patient III:1, in family A, CSF had been collected in 2012 and since then stored at $-80^{\circ} \mathrm{C}$. Levels of the neurodegenerative markers total tau ( $\mathrm{t}$-tau), phosphorylated tau ( $\mathrm{p}$-tau), $\beta$-amyloid $42 / 40(\mathrm{~A} \beta 42 / 40)$ ratio, and NFL chain and monoamine metabolites homovanillic acid (HVA), 5-hydroxyindoleacetic acid (5-HIAA) and 3-methoxy-4-hydroxyphenylglycol (MHPG) were determined (e-Methods, links.lww.com/ NXG/A160).

Figure Pedigrees of the 2 Swedish families with SPG10

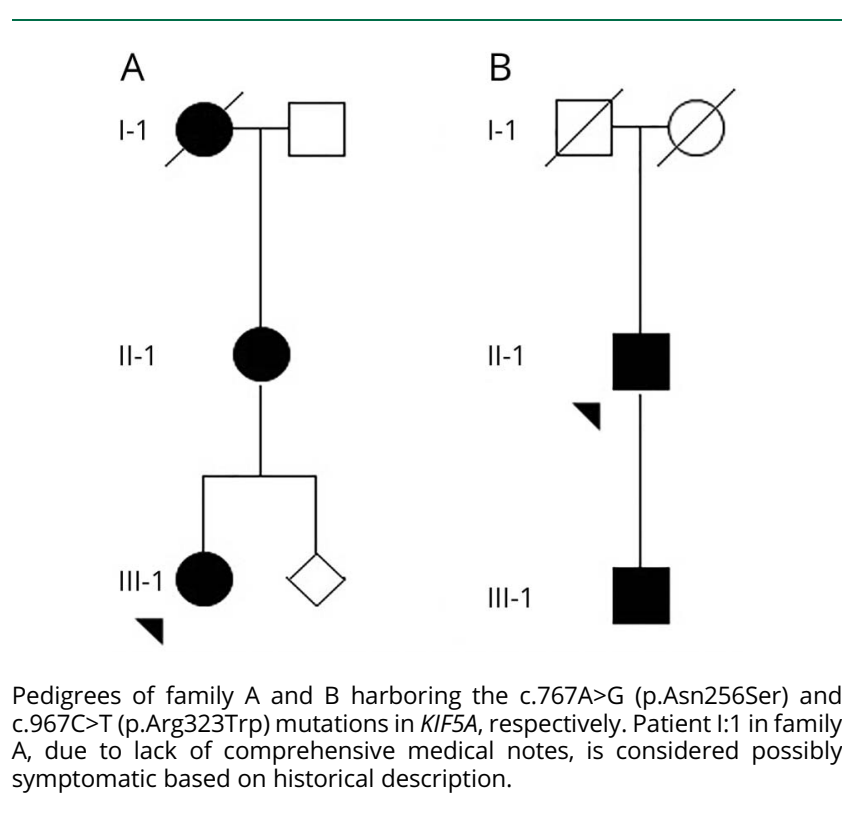




\section{Electrophysiology}

Motor and sensory nerve conduction studies were compiled from all 4 patients including, at a minimum, unilateral assessment of the median, peroneal, tibial, and sural nerves. Nerve conduction studies were conducted with Natus, Viking EDX (Cephalon A/S; Denmark). Quantitative sensory testing, detecting perception thresholds for cold and heat, was assessed bilaterally in the lateral foot and unilaterally in the hand with Medusa, TSA II (Cephalon A/S; Denmark).

\section{Neuroimaging}

Historic data from brain and spinal cord MRI were compiled and reviewed.

\section{Data availability statement}

Anonymized data will be shared by request from any qualified investigator.

\section{Results}

The previously reported heterozygous mutations in KIF5A, c.767A $>$ G (p.Asn256Ser) and c.967C $>\mathrm{T}$ (p.Arg323Trp) were found in family A and B, respectively. ${ }^{1,5}$ Briefly, all the affected patients presented with a variable degree of spastic paraparesis, which is in line with previous descriptions. ${ }^{1,2,5,7,8}$ Onset was at adult age in all but one case (III:1 in family B), in which the onset was insidious during childhood. All patients had variable degrees of polyneuropathy (PNP). The index case in family B reported neuropathic symptoms many years after onset of paraparesis, and electrodiagnostic testing demonstrated a moderate axonal sensorimotor PNP. The historical rate of overall clinical progression was slow in both families. We did not find evidence of cerebellar ataxia, psychiatric symptoms, or cognitive impairment. None of the patients were treated with psychotropic medications. Neuroimaging was normal. A summary of clinical, radiologic, and electrodiagnostic characteristics for both families is shown in table 1.

CSF-NFL was elevated only in the patient with the longest disease duration. In addition, and more unexpected, we found in all tested patients elevated CSF-HVA levels, and in 2 patients, CSF-MHPG was reduced. The serotonin metabolite (5-HIAA), A $442 / 40$ ratio, and $t$-tau and $p$-tau levels were normal. Results from CSF analyses are presented in table 2. Detailed case descriptions are included in the supplemental data (e-Clinical phenotypes, links.lww.com/ NXG/A161).

\section{Discussion}

There is a need for biomarkers and disease-modifying treatments for HSP diseases. The reasons for intrafamilial phenotype variability in SPG10 remain to be elucidated. ${ }^{1,7}$ This variation is similar to what is seen in other forms of familial

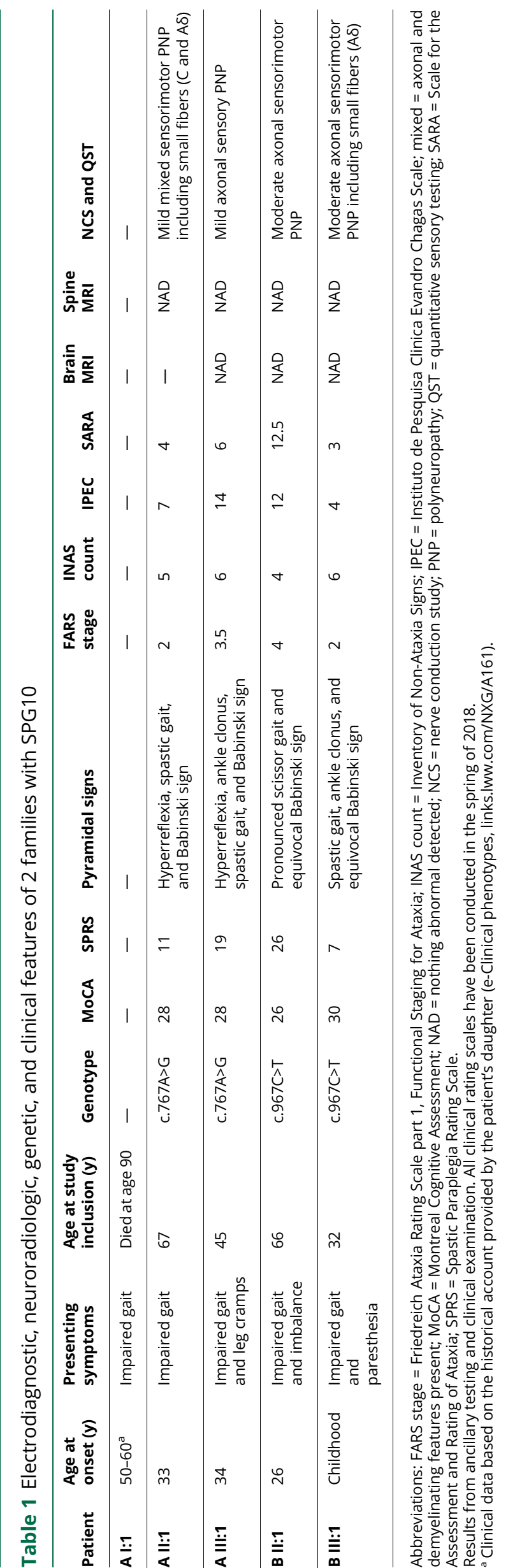


Table 2 CSF profiles of 3 patients with SPG10

\begin{tabular}{|c|c|c|c|c|c|c|c|}
\hline Patient & $\begin{array}{l}\text { t-Tau (pg/mL) } \\
{[<300(18-45 \text { years)] }} \\
{[<400 \text { (>45 years)] }}\end{array}$ & $\begin{array}{l}\text { p-Tau (pg/mL) } \\
{[<60(20-60 \text { years)] }} \\
{[<80 \text { (>60 years)] }}\end{array}$ & $\begin{array}{l}A \beta 42 / 40 \\
{[>0.89]}\end{array}$ & $\begin{array}{l}\text { NFL (pg/mL) } \\
{[<560(30-39 \text { years)] }} \\
{[<1850 \text { (>60 years)] }}\end{array}$ & $\begin{array}{l}\text { HVA } \\
\text { (nmol/L) } \\
{[40-170]}\end{array}$ & $\begin{array}{l}\text { 5-HIAA } \\
\text { (nmol/L) } \\
{[50-170]}\end{array}$ & $\begin{array}{l}\text { MHPG } \\
(\mathrm{nmol} / \mathrm{L}) \\
{[65-140]}\end{array}$ \\
\hline A I:1 & - & - & - & - & - & - & - \\
\hline A II:1 & - & - & - & - & - & - & - \\
\hline A III:1 & 24 & 26 & 0.90 & 517 & $208^{a}$ & 141 & $38^{a}$ \\
\hline B II:1 & 320 & 45 & 1.07 & $2,285^{a}$ & $237^{a}$ & 107 & 87 \\
\hline B III:1 & 171 & 32 & 1.02 & 432 & $272^{a}$ & 101 & $60^{a}$ \\
\hline
\end{tabular}

Abbreviations: 5-HIAA = 5-hydroxyindoleacetic acid; HVA = homovanillic acid; MHPG = 3-methoxy-4-hydroxyphenylglycol; NFL = neurofilament light. Biochemical characteristics of 3 patients with regard to markers of neurodegeneration and monoamine metabolism. A significant elevation of NFL in the patient in family B with the longest disease duration (II:1) is demonstrated, possibly reflecting axonal damage. Elevated HVA, reflecting increased dopamine turnover, is seen in all 3 patients. Furthermore, in 2 patients, biochemical signs of decreased noradrenergic turnover are present.

${ }^{a}$ Indicates value outside reference range.

kinesin motor proteinopathies such as SPG30 (KIF1A) and SPG58 (KIF1C); however, these diseases are biallelic and present with a more severe phenotype than SPG10. ${ }^{11,12}$

An impairment of axonal transport, with resulting lengthdependent axonal degeneration, forms the main theory of the underlying pathophysiology in SPG10. ${ }^{1}$ CSF levels of NFL, an important cytoskeletal component of the axon, were mildly elevated in the patient with longest disease duration. This patient also demonstrated the highest SPRS score (table 1). Because mutated KIF5A is known to impair axonal transport of neurofilaments, at least in vitro, we were expecting a more general elevation in our patients. ${ }^{9}$ However, NFL elevation was not evident in the 2 younger patients why such elevation cannot be viewed as an obligate finding in SPG10. These results are in contrast with studies in ALS, where NFL has been proposed as a biomarker. ${ }^{13}$ Furthermore, elevated CSF levels of phosphorylated neurofilament heavy chain in patients with HSP $(n=9)$ compared with controls have been reported in a previous study. ${ }^{14}$ It will be interesting to study NFL levels in patients with ALS harboring KIF5A mutations.

Assuming that intact axonal transport is important to maintain synaptic supply of monoamines, we analyzed these metabolites. Surprisingly, CSF-HVA was elevated in all tested patients, of which none had a history of mood disturbance, psychotic behaviors, or treatment with psychotropic drugs. Thus, the clinical correlates of this abnormality is unclear. In addition, 2 patients had decreased levels of the noradrenergic metabolite MHPG in CSF. In keeping with the proposed pathophysiology of an underlying axonopathy in SPG10, deficiency of various neurotransmitters such as noradrenaline may either reflect impaired transportation of synaptic proteins or an epiphenomenon. Regardless, the specificity of these abnormalities remains to be explained.

Small sample size is the main limitation of this study. In addition, we cannot rule out that the prolonged CSF storage time (III: 1 in family A) might have underestimated the values of $t$-tau and $A \beta 42 / 40$ ratio.

Previous reports on the CSF profile in patients with KIF5A mutations are rare. Thus, future studies in larger cohorts are needed to better discern whether noradrenergic deficiency and increased dopaminergic neurotransmission are prevalent findings in SPG10, other kinesin proteinopathies, and/or patients with ALS with KIF5A mutations. It will also be important to delineate potential clinical correlates to these changes in monoaminergic neurotransmission.

\section{Acknowledgment}

The authors are grateful to the patients who participated in the study. Funding was obtained from the ALF program at the Stockholm City Council. P. Svenningsson is a Wallenberg Clinical Scholar. M. Paucar obtained funding from the Swedish Society for Medical Research.

\section{Study funding}

This study was funded by the collaboration agreement between Karolinska Institutet and Stockholm County Council (ALF). Per Svenningsson is a Wallenberg Clinical Scholar. Martin Paucar obtained funding from the Swedish Society for Medical Research.

\section{Disclosure}

M. Andréasson has received a contribution from NEURO Sweden (Neuroförbundet) for another study. K. LagerstedtRobinson and K. Samuelsson report no disclosures. G. Solders has received an unconditional grant from Sanofi/ Genzyme for another study. K. Blennow has served as a consultant or at advisory boards for Alector, Alzheon, CogRx, Biogen, Lilly, Novartis, and Roche Diagnostics and is a cofounder of Brain Biomarker Solutions in Gothenburg $A B$, a GU Venture-based platform company at the University of Gothenburg, all unrelated to the work presented in this article. M. Paucar and P. Svenningsson report no disclosures. Go to Neurology.org/NG for full disclosures. 


\section{Publication history}

Received by Neurology: Genetics February 6, 2019. Accepted in final form May 13, 2019.

Appendix Authors

\begin{tabular}{|c|c|c|c|}
\hline Name & Location & Role & Contribution \\
\hline $\begin{array}{l}\text { Mattias } \\
\text { Andréasson, } \\
\text { MD }\end{array}$ & $\begin{array}{l}\text { Karolinska } \\
\text { University Hospital, } \\
\text { Karolinska Institutet } \\
\text { and Academic } \\
\text { Specialist Center, } \\
\text { Stockholm }\end{array}$ & Author & $\begin{array}{l}\text { Drafting and } \\
\text { revision of the } \\
\text { manuscript; study } \\
\text { concept and design; } \\
\text { and analysis and } \\
\text { interpretation of } \\
\text { data }\end{array}$ \\
\hline $\begin{array}{l}\text { Kristina } \\
\text { Lagerstedt- } \\
\text { Robinson, PhD }\end{array}$ & $\begin{array}{l}\text { Karolinska } \\
\text { University Hospital } \\
\text { and Karolinska } \\
\text { Institutet, } \\
\text { Stockholm }\end{array}$ & Author & $\begin{array}{l}\text { Interpretation of } \\
\text { genetic tests and } \\
\text { revision of the } \\
\text { manuscript }\end{array}$ \\
\hline $\begin{array}{l}\text { Kristin } \\
\text { Samuelsson, } \\
\text { MD, PhD }\end{array}$ & $\begin{array}{l}\text { Karolinska } \\
\text { University Hospital, } \\
\text { Stockholm }\end{array}$ & Author & $\begin{array}{l}\text { Interpretation of } \\
\text { data and revision of } \\
\text { the manuscript }\end{array}$ \\
\hline $\begin{array}{l}\text { Göran Solders, } \\
\text { MD, PhD }\end{array}$ & $\begin{array}{l}\text { Karolinska } \\
\text { University Hospital, } \\
\text { Stockholm }\end{array}$ & Author & $\begin{array}{l}\text { Interpretation of } \\
\text { neurophysiologic } \\
\text { studies and clinical } \\
\text { data and revision of } \\
\text { the manuscript }\end{array}$ \\
\hline $\begin{array}{l}\text { Kaj Blennow, } \\
\text { MD, PhD }\end{array}$ & $\begin{array}{l}\text { Clinical } \\
\text { Neuroscience, } \\
\text { University of } \\
\text { Gothenburg }\end{array}$ & Author & $\begin{array}{l}\text { CSF analyses; } \\
\text { interpretation of } \\
\text { data; and revision of } \\
\text { the manuscript }\end{array}$ \\
\hline $\begin{array}{l}\text { Martin Paucar, } \\
\text { MD, PhD }\end{array}$ & $\begin{array}{l}\text { Karolinska } \\
\text { University Hospital } \\
\text { and Karolinska } \\
\text { Institute, Stockholm }\end{array}$ & Author & $\begin{array}{l}\text { Revision of the } \\
\text { manuscript; study } \\
\text { concept and design; } \\
\text { analysis and } \\
\text { interpretation of } \\
\text { data; and study } \\
\text { supervision and } \\
\text { coordination }\end{array}$ \\
\hline
\end{tabular}

Appendix (continued)

\begin{tabular}{|c|c|c|c|}
\hline Name & Location & Role & Contribution \\
\hline $\begin{array}{l}\text { Per } \\
\text { Svenningsson, } \\
\text { MD, PhD }\end{array}$ & $\begin{array}{l}\text { Karolinska } \\
\text { University Hospital } \\
\text { and Karolinska } \\
\text { Institute, Stockholm }\end{array}$ & Author & $\begin{array}{l}\text { Revision of the } \\
\text { manuscript; } \\
\text { analysis and } \\
\text { interpretation of } \\
\text { data; study } \\
\text { supervision and } \\
\text { coordination; and } \\
\text { obtaining funding }\end{array}$ \\
\hline
\end{tabular}

\section{References}

1. Reid E, Kloos M, Ashley-Koch A, et al. A kinesin heavy chain (KIF5A) mutation in hereditary spastic paraplegia (SPG10). Am J Hum Genet 2002;71:1189-1194.

2. Liu Y, Laurá M, Hersheson J, et al. Extended phenotypic spectrum of KIF5A mutations: from spastic paraplegia to axonal neuropathy. Neurology 2014;83:612-619.

3. Nicolas A, Kenna KP, Renton AE, et al. Genome-wide analyses identify KIF5A as a novel ALS gene. Neuron 2018;97:1268-1283.

4. Hirokawa N, Noda Y, Tanaka Y, Niwa S. Kinesin superfamily motor proteins and intracellular transport. Nat Rev Mol Cell Biol 2009;10:682-696.

5. Rinaldi F, Bassi MT, Todeschini A, et al. A novel mutation in motor domain of KIF5A associated with an HSP/axonal neuropathy phenotype. J Clin Neuromuscul Dis 2015; 16:153-158.

6. Ebbing B, Mann K, Starosta A, et al. Effect of spastic paraplegia mutations in KIF5A kinesin on transport activity. Hum Mol Genet 2008;17:1245-1252.

7. López E, Casasnovas C, Giménez J, Santamaría R, Terrazas JM, Volpini V. Identification of two novel KIF5A mutations in hereditary spastic paraplegia associated with mild peripheral neuropathy. J Neurol Sci 2015;358:422-427.

8. Collongues N, Depienne C, Boehm N, et al. Novel SPG10 mutation associated with dysautonomia, spinal cord atrophy, and skin biopsy abnormality. Eur J Neurol 2013 20:398-401.

9. Wang L, Brown A. A hereditary spastic paraplegia mutation in kinesin-1A/KIF5A disrupts neurofilament transport. Mol Neurodegener 2010;5:52.

10. Karle KN, Möckel D, Reid E, Schöls L. Axonal transport deficit in a KIF5A(-/-) mouse model. Neurogenetics 2012;13:169-179.

11. Dor T, Cinnamon Y, Raymond L, et al. KIF1C mutations in two families with hereditary spastic parapares and cerebellar dysfunction. J Med Genet 2014;51:137-142.

12. Erlich Y, Edvardson S, Hodges E, et al. Exome sequencing and disease-network analysis of a single family implicate a mutation in KIF1A in hereditary spastic paraparesis. Genome Res 2011;21:658-664.

13. Gaiani A, Martinelli I, Bello L, et al. Diagnostic and prognostic biomarkers in amyotrophic lateral sclerosis: neurofilament light chain levels in definite subtypes of disease. JAMA Neurol 2007;74:525-532.

14. Zucchi E, Bedin R, Fasano A, et al. Cerebrospinal fluid neurofilaments may discriminate upper motor neuron syndromes: a pilot study. Neurodegener Dis 2018;18:255-261. 


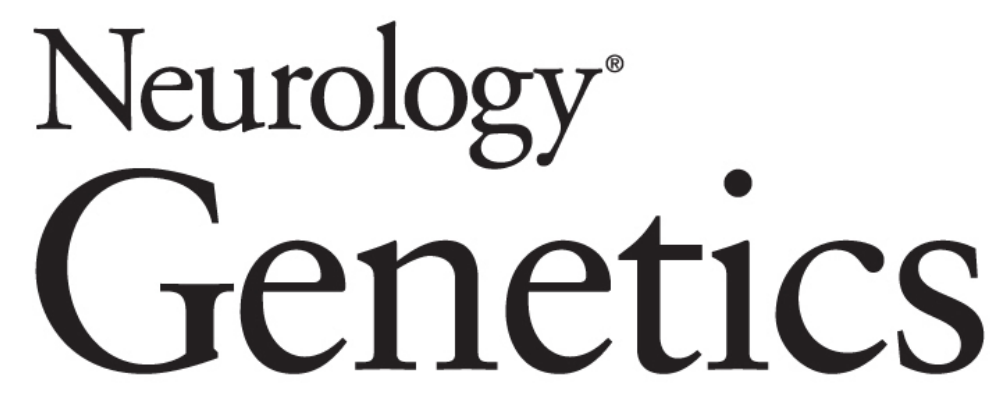

Altered CSF levels of monoamines in hereditary spastic paraparesis 10: A case series Mattias Andréasson, Kristina Lagerstedt-Robinson, Kristin Samuelsson, et al. Neurol Genet 2019;5;

DOI 10.1212/NXG.0000000000000344

This information is current as of June 12, 2019
Updated Information \& Services
including high resolution figures, can be found at: http://ng.neurology.org/content/5/4/e344.full.html
References
This article cites 14 articles, 2 of which you can access for free at: http://ng.neurology.org/content/5/4/e344.full.html\#\#ref-list-1
Subspecialty Collections
This article, along with others on similar topics, appears in the following collection(s):
Spastic paraplegia
http://ng.neurology.org//cgi/collection/spastic_paraplegia
Permissions \& Licensing
Information about reproducing this article in parts (figures,tables) or in its entirety can be found online at:
http://ng.neurology.org/misc/about.xhtml\#permissions
Reprints
Information about ordering reprints can be found online: http://ng.neurology.org/misc/addir.xhtml\#reprintsus

Neurol Genet is an official journal of the American Academy of Neurology. Published since April 2015, it is an open-access, online-only, continuous publication journal. Copyright Copyright () 2019 The Author(s). Published by Wolters Kluwer Health, Inc. on behalf of the American Academy of Neurology.. All rights reserved. Online ISSN: 2376-7839.

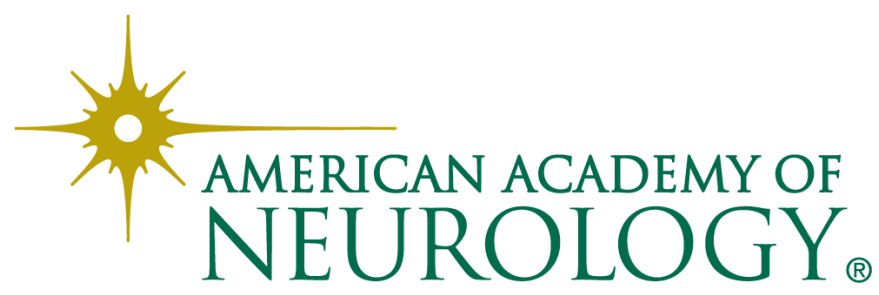

